\title{
Rectal angiolipoma: A case report and review of literature
}

\author{
Sabite Kacar, Sedef Kuran, Tulay Temucin, Bulent Odemis, Nilufer Karadeniz, Nurgul Sasmaz
}

Sabite Kacar, Sedef Kuran, Bulent Odemis, Nurgul Sasmaz, Gastroenterology Department, Türkiye Yüksek Ihtisas Hospital, Ankara, Turkey

Tulay Temucin, Pathology Department, Türkiye Yüksek Ihtisas Hospital, Ankara, Turkey

Nilufer Karadeniz, Genetic Department, Zekai Tahir Burak Training and Research Hospital, Ankara, Turkey

Correspondence to: Sedef Kuran, MD, Gastroenterology Department, Türkiye Yüksek Ihtisas Hospital, Dikmen Cad., 220/ A, No.17, Dikmen, Ankara, Turkey. sedefozdal@hotmail.com Telephone: +90-533-3479969 Fax: +90-312-3124120

Received: 2006-12-14

Accepted: 2007-01-27

\begin{abstract}
Angiolipoma is a rare vascular variant of the benign lipomatous tumors and is generally seen in subcutaneous tissues. We report a 70-year-old female with abdominal distension not related to rectal small polypoid mass with peduncule described as angiolipoma by histologically, and review the literature.
\end{abstract}

(C) 2007 The WJG Press. All rights reserved.

Key words: Gastrointestinal tract angiolipoma; Gastrointestinal benign lipomatous tumors; Rectal angiolipoma

Kacar S, Kuran S, Temucin T, Odemis B, Karadeniz N, Sasmaz N. Rectal angiolipoma: A case report and review of literature. World J Gastroenterol 2007; 13(9): 1460-1465

http://www.wjgnet.com/1007-9327/13/1460.asp

\section{INTRODUCTION}

Lipomas, lipomatosis, lipoblastoma, lipoblastomatosis, angiolipomas, myolipomas, chondroid lipomas, spindle cell lipomas, and pleomorphic lipomas are the benign adipose tissue tumors ${ }^{[1]}$. Angiolipoma is one of the rare subcutaneous tissue tumors with its characteristic histology consisting of mature adipose tissue and interspersed proliferated vascular component $t^{[1-3]}$. It accounts for $5 \%-17 \%$ of lipomas ${ }^{[2,45}$, and is rarely seen in the gastrointestinal system (GIS). The locations of gastrointestinal angiolipoma according to the current literature are oropharyngeal region ${ }^{[4,6-8]}$, esophagus ${ }^{[0]}$, stomach $^{[10-13]}$, duodenum ${ }^{[14,15]}$, small intestine ${ }^{[3,16-18]}$, ileocecal valve $^{[19-21]}$, colon ${ }^{[14,22-24]}$ and liver ${ }^{[25-28]}$. Angiolipomas localized in the gastrointestinal tract, characterized as submucosal solitary sessile ${ }^{[10,11,18,20]}$ or endoluminal polypoid lesions ${ }^{[9,12,14,23,24]}$, are diagnosed generally by postoperative histopathologic evaluation or after polypectomy. Radiologic techniques such as barium radiographs, enteroclysis, abdominal ultrasound, computed tomography (CT), and magnetic resonance imaging (MRI) can demonstrate the lesion in the gastrointestinal tract before histopathologic diagnosis $^{[24]}$

\section{CASE REPORT}

A 70-year-old woman admitted to the hospital with complaints of abdominal distension and constipation. She had no abdominal pain, rectal bleeding or weight loss. Her total blood count, serum biochemistry, sedimentation rate and abdominal ultrasound were normal. A polyp $(1 \mathrm{~cm}$ in diameter) with lobulated and degenerated hyperemic mucosa and normal peduncle was seen at proximal rectum. Polypectomy was performed by endoscopic polypectomy snare and no complication occurred. Angiolipoma was diagnosed after histopathologic evaluation in mature adipose tissue and proliferous blood vessels (Figure 1). There was no fibrin thrombus and no muscle structure in histologic examination with HMB45 (monoclonal mouse anti-human melanosome, Dako, USA) and anti-smooth muscle antibody (mouse anti-human primary alpha-smooth muscle actin, Dako, USA) tissue stainings. There were no other lesions in total colonoscopy and esophagogastroduo denoscopy. No photograph of the polyp was taken before resection because externally there was no special difference in adenomatous polyps with degenerated surface mucosa.

\section{DISCUSSION}

Angiolipomas are benign lipomatous lesions, which were first defined by Bowen ${ }^{[29]}$ in 1912 and differentiated from lipomas histopathologically by Howard in $1960^{[30]}$. The lipomatous benign lesions are seen as musculoskeletal masses especially in soft tissues and bones ${ }^{[1,2]}$. They are generally subcutaneous and capsulated, about $50 \%$ patients feel painful on palpation, and seen in young adult males in their 2 nd or 3 rd decades of life ${ }^{[1,2,24]}$. They are also localized in neck ${ }^{[4,31]}$, maxillofacial region ${ }^{[32-35]}$ and nonsubcutaneous tissues such as epidural ${ }^{[36]}$, spinal ${ }^{[37-39]}$, and suprasellar tissues ${ }^{[40]}$. Lipomas are seen more frequently, but angiolipomas are rare lesions ${ }^{[1,5]}$. Gastrointestinal angiolipoma is also a rare pathological condition ${ }^{[1,24]}$. The other uncommon localizations of angiolipomas are the renal tissue ${ }^{[41-44]}$, adrenal tissue ${ }^{[45,46]}$, breast ${ }^{[47]}$, thyroid gland ${ }^{[48]}$, parotid gland ${ }^{[49]}$, mediastinum ${ }^{[50]}$, orbits ${ }^{[51]}$, myocardium $^{[52]}$ and scrotum ${ }^{[33]}$. 

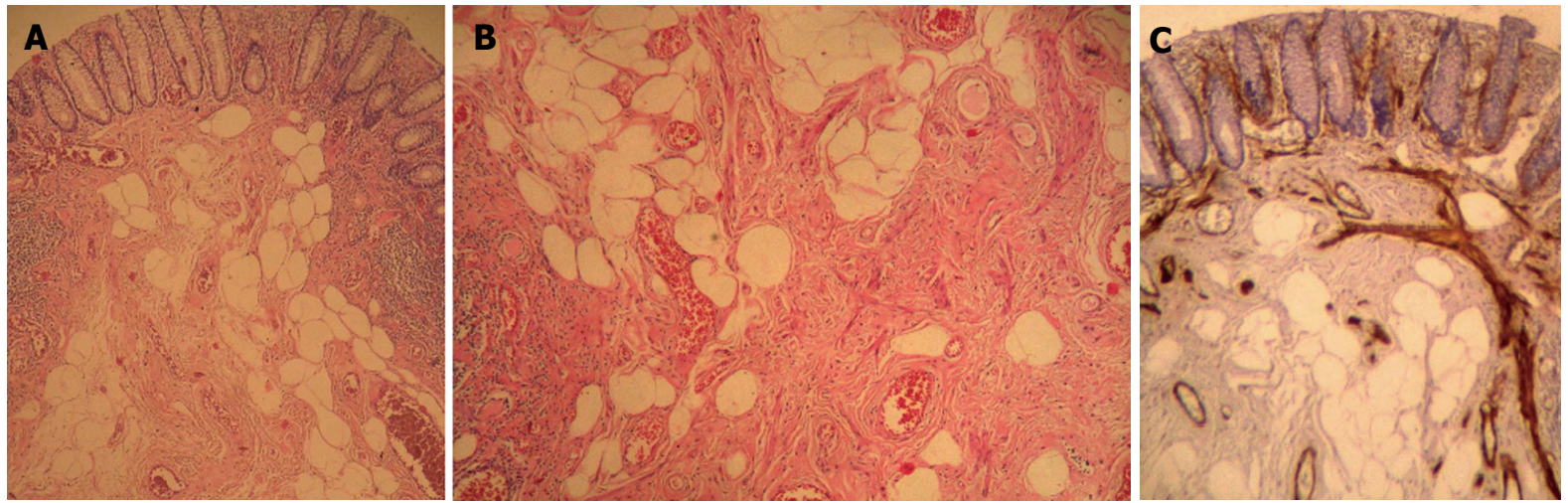

Figure 1 Histopathologic appearance of small rectal pedunculated angiolipoma (macroscopically $7 \mathrm{~mm} \times 5 \mathrm{~mm} \times 4 \mathrm{~mm}$ in diameter with normal mucosal appearence). A: Proliferated blood vessels and adipose cells in mature adipose tissue in submucosa of colon at small magnification (light microscope, $\mathrm{HE}$ ); $\mathbf{B}$ : Proliferated vascular tissues and mature adipose tissue in submucosa. There was no fibrin trombus in blood vessels (light microscope, HE); C: SMA staining of angiolipoma.

Table 1 Gastrointestinal angiolipomas defined in literature

\begin{tabular}{|c|c|c|c|c|c|c|c|c|}
\hline Literature & Localization & $\begin{array}{c}\text { Case } \\
\text { (age/sex) }\end{array}$ & Polyp size & Polyp peduncle & Symptom & $\begin{array}{l}\text { Preoperative } \\
\text { diagnostic } \\
\text { imaging } \\
\text { methods } \\
\text { (except } \\
\text { endoscopic } \\
\text { procedure) }\end{array}$ & Therapy & $\begin{array}{l}\text { Follow-up } \\
(\mathrm{F} / \mathrm{U}) / \\
\text { recurrence }\end{array}$ \\
\hline $\begin{array}{l}\text { Jensen EH et al }{ }^{[9]} \\
2006\end{array}$ & Esophagus & $85 \mathrm{yr} / \mathrm{M}$ & $\begin{array}{c}39 \mathrm{~mm} \times 25 \\
\mathrm{~mm}\end{array}$ & $\begin{array}{l}5 \text { Pedunculated } \\
\text { large polyp }\end{array}$ & $\begin{array}{l}\text { A 2-mo } \\
\text { dysphagia to } \\
\text { solids foods, } \\
\text { complete } \\
\text { esophageal } \\
\text { obstruction; } \\
\text { had prolapsed } \\
\text { to the level of } \\
\text { the GE junction }\end{array}$ & CT, EUS & $\begin{array}{l}\text { Anterior esophagotomy, } \\
\text { transsection of } \\
\text { polyp using an } \\
\text { endoscopic } \\
\text { stapling device } \\
\text { (open surgical excision) }\end{array}$ & No F/U \\
\hline $\begin{array}{l}\text { DeRidder Ph } \\
\text { et al }^{[10]}(1989)\end{array}$ & Stomach & $59 \mathrm{yr} / \mathrm{M}$ & $6 \mathrm{~mm}$ & $\begin{array}{l}\text { Submucosal well } \\
\text { demarcated mass }\end{array}$ & $\begin{array}{l}\text { Chronic occult } \\
\text { GI bleeding }\end{array}$ & & $\begin{array}{l}\text { Laparotomy- } \\
\text { excision }\end{array}$ & $\begin{array}{l}12 \mathrm{mo} / \mathrm{No} \\
\text { recurrence }\end{array}$ \\
\hline $\begin{array}{l}\text { McGregor DH } \\
\text { et al }{ }^{[11]} \\
(1993)\end{array}$ & Stomach & $69 \mathrm{yr} / \mathrm{M}$ & $\begin{array}{l}50 \mathrm{~mm} \\
\times 40 \mathrm{~mm} \\
\times 20 \mathrm{~mm}\end{array}$ & $\begin{array}{l}\text { Gastric } \\
\text { submucosal } \\
\text { mass on great } \\
\text { curvature, } \\
\text { without peduncle }\end{array}$ & $\begin{array}{l}\text { Chronic hemorrhage } \\
\text { and severe anemia }\end{array}$ & & $\begin{array}{l}\text { Exploratory } \\
\text { laparotomy, } \\
\text { mass resection }\end{array}$ & $\begin{array}{l}30 \mathrm{mo} / \mathrm{No} \\
\text { recurrence }\end{array}$ \\
\hline $\begin{array}{l}\text { Hunt J et al }{ }^{[12]} \\
\text { (1996) }\end{array}$ & Stomach & $27 \mathrm{yr} / \mathrm{F}$ & $\begin{array}{l}80 \mathrm{~mm} \\
\times 55 \mathrm{~mm} \\
\times 45 \mathrm{~mm}\end{array}$ & $\begin{array}{l}\text { Large polypoid } \\
\text { mass with } \\
\text { large peduncle }\end{array}$ & $\begin{array}{l}\text { Suggestive of } \\
\text { intussusception } \\
\text { through the pylorus, } \\
\text { acute GI hemorrhage }\end{array}$ & & $\begin{array}{l}\text { Exploratory laparotomy, } \\
\text { distal partial } \\
\text { gastrectomy, } \\
\text { Billroth I gastric } \\
\text { reconstruction, } \\
\text { resection of polyp }\end{array}$ & $\begin{array}{l}\text { not given/ } \\
\text { No } \\
\text { recurrence }\end{array}$ \\
\hline $\begin{array}{l}\text { Mohl W et al }{ }^{[14]} \\
(2004)^{2}\end{array}$ & $\begin{array}{l}\text { Duodenum, } \\
\text { Colon }\end{array}$ & $\begin{array}{l}\text { The first was } \\
66 \mathrm{yr} / \mathrm{M} \text {, the } \\
\text { second was } \\
75 \mathrm{yr} / \mathrm{F} \mathrm{(2} \\
\text { pts with } 1 \\
\text { duodenal } \\
\text { and colonic } \\
\text { A-L other } \\
\text { duodenal } \\
\text { A-Ls) }\end{array}$ & $\begin{array}{c}\text { 1st-10 mm } \\
\text { located near } \\
\text { papilla of } \\
\text { Vater, and } \\
\text { colon } \\
\text { 2nd-23 mm } \\
\text { at the upper } \\
\text { duodenal } \\
\text { knee }\end{array}$ & $\begin{array}{l}\text { Both with } \\
\text { peduncle }\end{array}$ & $\begin{array}{l}\text { 1st acute, 2nd chronic } \\
\text { GI bleeding } \\
\text { Upper GI bleeding due } \\
\text { to duodenal } \\
\text { A-L }\end{array}$ & & $\begin{array}{l}\text { Endoscopic snare } \\
\text { polypectomy for } 2 \\
\text { duodenal and for } 1 \\
\text { colonic A-Ls }\end{array}$ & $\begin{array}{l}\text { not given/ } \\
\text { No } \\
\text { recurrence }\end{array}$ \\
\hline $\begin{array}{l}\text { Jung IS et al }{ }^{[15]} \\
(2004)\end{array}$ & Duodenum & $60 \mathrm{yr} / \mathrm{F}$ & $\begin{array}{c}35 \mathrm{~mm} \times 4 \\
\mathrm{~mm}\end{array}$ & With peduncle & Dyspepsia for $6 \mathrm{mo}$ & EUS & $\begin{array}{l}\text { Endoscopic } \\
\text { polypectomy }\end{array}$ & No $F / U$ \\
\hline $\begin{array}{l}\text { Kaneko T et al }^{[16]} \\
(1996)^{1}\end{array}$ & $\begin{array}{c}\text { Meckel's } \\
\text { diverticulum } \\
\text { accompanied } \\
\text { A-L }\end{array}$ & & & & Intussusception & & & \\
\hline $\begin{array}{l}\text { Ferrozzi F et al } l^{[3]} \\
(1998)\end{array}$ & Ileal & & & & With tuberous sclerosis & CT & & \\
\hline
\end{tabular}




\begin{tabular}{|c|c|c|c|c|c|c|c|c|}
\hline $\begin{array}{l}\text { Manner M et } \\
a l^{[17]} \\
(2001)\end{array}$ & $\begin{array}{l}\text { Proximal } \\
\text { ileum }\end{array}$ & $71 \mathrm{yr} / \mathrm{F}$ & $38 \mathrm{~mm}$ & With peduncle & $\begin{array}{l}\text { Occult bleeding, } \\
\text { ileoileal } \\
\text { intussusception }\end{array}$ & US, CT & $\begin{array}{l}\text { Small bowel } \\
\text { resection }\end{array}$ & \\
\hline $\begin{array}{l}\text { Kwak HS et al }{ }^{[18]} \\
\text { (2003) }\end{array}$ & $\begin{array}{l}\text { Small bowel/ } \\
\text { proximal } \\
\text { ileum }\end{array}$ & $75 \mathrm{yr} / \mathrm{M}$ & $30 \mathrm{~mm}$ & $\begin{array}{l}\text { Intraluminal } \\
\text { lobulated } \\
\text { polypoid mass } \\
\text { with peduncle }\end{array}$ & $\begin{array}{l}\text { Epigastric discomfort, } \\
\text { loss of appetite, weight } \\
\text { loss }\end{array}$ & $\begin{array}{c}\text { Enteroclysis, } \\
\text { MRI }\end{array}$ & Surgery & No F/U \\
\hline $\begin{array}{l}\text { Aouad Ket al }{ }^{[19]} \\
(2000)\end{array}$ & $\begin{array}{c}\text { (Bauhin valve) } \\
\text { ileocecal } \\
\text { valve }\end{array}$ & & & & $\begin{array}{l}\text { Gastrointestinal } \\
\text { hemorrhage }\end{array}$ & & & \\
\hline $\begin{array}{l}\text { Kato K et al }{ }^{[20]} \\
(1999)^{1}\end{array}$ & $\begin{array}{l}\text { Ileocecal } \\
\text { valve }\end{array}$ & $69 \mathrm{yr} / \mathrm{M}$ & $\begin{array}{c}52 \mathrm{~mm} \times \\
50 \mathrm{~mm} \times 40 \\
\mathrm{~mm}\end{array}$ & $\begin{array}{l}\text { Without peduncle, } \\
\text { a submucosal } \\
\text { smooth surface } \\
\text { mass A-L }\end{array}$ & $\begin{array}{l}\text { 3-d right lower } \\
\text { quadrant abdominal } \\
\text { pain }\end{array}$ & $\begin{array}{c}\text { Contrast } \\
\text { enhanced } \\
\text { abdominal CT }\end{array}$ & $\begin{array}{l}\text { Laparoscopy-assisted } \\
\text { ileocecostomy, } \\
\text { and a side-to- } \\
\text { side anastomosis } \\
\text { extracorporeally } \\
\text { (a minimally } \\
\text { invasive laparoscopic } \\
\text { technique) }\end{array}$ & $\begin{array}{l}5 \mathrm{yr} / \mathrm{No} \\
\text { recurrence }\end{array}$ \\
\hline $\begin{array}{l}\text { Saroglia Get } \\
a l^{[21]} \\
(1996)\end{array}$ & Ileocecal valve & $55 \mathrm{yr} / \mathrm{M}$ & $55 \mathrm{~mm}$ & Submucousal mass & Invagination & $\begin{array}{l}\text { Barium } \\
\text { contrast } \\
\text { graphy }\end{array}$ & Surgery & No F/U \\
\hline $\begin{array}{l}\text { Vandamme J } \\
\text { et al }{ }^{[22]}(1964)\end{array}$ & $\begin{array}{l}\text { Descending } \\
\text { colon }\end{array}$ & $43 \mathrm{yr} / \mathrm{M}$ & $\begin{array}{c}150 \mathrm{~mm} \times 40 \\
\mathrm{~mm}\end{array}$ & With peduncle & $\begin{array}{l}\text { GI bleeding and } \\
\text { non painful sub- } \\
\text { obstruction by } \\
\text { invagination }\end{array}$ & $\begin{array}{l}\text { Barium } \\
\text { contrast } \\
\text { graphy }\end{array}$ & Surgery, colon resection & $\begin{array}{l}\text { not given/ } \\
\text { No } \\
\text { recurrence }\end{array}$ \\
\hline $\begin{array}{l}\text { Okuyama T } \\
\text { et al } l^{[23]}(2002)\end{array}$ & Sigmoid colon & $49 \mathrm{yr} / \mathrm{M}$ & $\begin{array}{c}65 \mathrm{~mm} \times 23 \\
\mathrm{~mm}\end{array}$ & $\begin{array}{l}\text { Pedunculated } \\
\text { polyp with } \\
\text { smooth surface }\end{array}$ & $\begin{array}{l}\text { Asymptomatic, during } \\
\text { routine exam } \\
\text { positive fecal blood }\end{array}$ & $\begin{array}{c}\text { Double } \\
\text { contrast } \\
\text { enema, } \\
\text { enhanced CT }\end{array}$ & $\begin{array}{l}\text { Hemostatic clip and } \\
\text { endoscopic electro- } \\
\text { surgical polypectomy }\end{array}$ & No F/U \\
\hline $\begin{array}{l}\text { Chen YY et al }{ }^{[24]} \\
(2005)\end{array}$ & $\begin{array}{l}\text { Transvers } \\
\text { colon }\end{array}$ & $70 \mathrm{yr} / \mathrm{M}$ & $50 \mathrm{~mm}$ & With peduncle & Colonic obstruction & $\begin{array}{c}\text { US, } \\
\text { Abdominal } \\
\text { CT, Colonic } \\
\text { barium } \\
\text { enema, } \\
\text { colonoscopic } \\
\text { examination }\end{array}$ & $\begin{array}{l}\text { Surgical segmental } \\
\text { resection }\end{array}$ & $\begin{array}{l}2 \mathrm{yr} / \mathrm{No} \\
\text { recurrence }\end{array}$ \\
\hline Kacar S et al & Rectum & $70 \mathrm{yr} / \mathrm{F}$ & $10 \mathrm{~mm}$ & With peduncle & Asymptomatic & - & $\begin{array}{l}\text { Polypectomy performed } \\
\text { by endoscopic } \\
\text { polypectomy snare }\end{array}$ & $\begin{array}{l}6 \mathrm{mo} / \mathrm{No} \\
\text { recurrence } \\
\text { Under } \mathrm{F} / \mathrm{U}\end{array}$ \\
\hline
\end{tabular}

${ }^{1}$ Abstract of reference (full text not available); ${ }^{2}$ Three lesions of angiolipoma in two patients, were defined. GE: Gastroesophageal; A-L: Angiolipoma.

In the musculoskeletal system, angiolipomas are $70 \%$ multiple and $10 \%$ familial ${ }^{[5]}$. It can have an autosomal dominant penetrance ${ }^{[1,22]}$. The mode of inheritence in GIS is still not clear ${ }^{[54]}$

Histologically, it is comprised of mature adipose tissue and proliferated vascular tissues. It can be classified as predominantly lipomatous or angiomatous type, based on the ratio of adipose tissue and vascular tissue composition $^{[1,2,5]}$. Fibrin thrombus due to microtraumas is generally seen in angiomatous lesions ${ }^{[5,11,20,23,48]}$. Angiolipomas localized in muscle and cutaneous tissue can have two different behavior patterns: infiltrative or non-infiltrative ${ }^{[5]}$. But the gastrointestinal cases defined in the literature have been non-infiltrating and showed no recurrence during follow-up periods (Table 1).

Eight maxillofacial angiolipomas had been reported in the literature until $1989^{[7]}$ and 17 head and neck angiolipomas until $1999^{[4]}$. There are also cases in the literature of oropharyngeal angiolipomas including tongue, cheek mucosa and palate ${ }^{[4,6-8]}$.

Angiolipomas localized in the GIS or liver. Although hepatic localization of lipomatous tumors is seen more frequently than gastrointestinal tract, hepatic angiolipomas are also rare lesions in this group ${ }^{[27,28,55,56]}$. Most lipomatous lesions of the liver ${ }^{[55,56]}$ and hepatic angiolipomas are associated with tuberous sclerosis complex ${ }^{[2]}$.

Seven cases of angiolipoma hade been reported in the gastrointestinal tract in the literature up to $2005^{[24]}$. To the best of our knowledge, 17 cases of gastrointestinal angiolipoma have been reported to date (1 esophageal ${ }^{[0]}, 3$ gastric $^{[10-12]}, 2$ duodenal ${ }^{[14,15]}, 4$ small bowel ${ }^{[3,16-18]}, 3$ ileocecal valve $^{[19-21]}$, and 4 colonic) ${ }^{[14,22-24]}$. Based on these reports, our case would be the first angiolipoma defined in the rectum.

There are syndromes accompanying angiolipomas, such as familial angiolipomatosis, which is rare and benign with mostly autosomal dominant inheritance and multiple angiolipomas of the extremities and trunk ${ }^{[57]}$. Birt-HoggDube syndrome is an autosomal-dominant condition characterized by fibrofolliculomas, trichodiscomas, and acrochordons $^{[58]}$. There is only one ileal angiolipomaassociated tuberous sclerosis in the literature $e^{[3]}$. Hunt et al ${ }^{[12]}$ described a case with solitary gastric Peutz-Jeghers polyp and angiolipoma presenting as acute hemorrhage.

Angiolipamas are diagnosed generally as single lesions in the gastrointestinal tract, but Mohl et a ${ }^{[14]}$ described a case of both colonic and duodenal angiolipoma. Angiolipomas in the gastrointestinal tract, as shown in Table 1, can be sessile ${ }^{[10,11,18,20]}$ or pedunculated polypoid 
Table 2 Histopathological findings of cases in literature

\begin{tabular}{|c|c|}
\hline e & roscope \\
\hline & $\begin{array}{l}\text { A subr } \\
\text { lipoma } \\
\text { consist }\end{array}$ \\
\hline DeRidder et $\mathrm{l}^{[10]}$ & $\begin{array}{l}\text { Submucosa contained a well } \\
\text { composed of flat, extending from } \\
\text { the muscularis mucosa to the de } \\
\text { There were separate, well deve } \\
\text { and veins }\end{array}$ \\
\hline McGregor D et al ${ }^{[1]]}$ & $\begin{array}{l}\text { A circumbscribed, lobular, pinkish-tan soft ovoid } \\
\text { mass showing proliferation of mature adipose tissue } \\
\text { and vascular tissue surrounded by a thin to focally } \\
\text { thick fibrous capsule in the submucosa, no definite } \\
\text { fibrin trombi }\end{array}$ \\
\hline Hunt $\mathrm{J} e$ & $\begin{array}{l}\text { y Peutz-Jeghers-type polyp showing typical } \\
\text { ar epithelium, overriding a } 5 \mathrm{~cm} \text { gastric } \\
\text { oma }\end{array}$ \\
\hline Mohl W et al ${ }^{[14]}$ & $\begin{array}{l}\text { l duodenal angiolipomas, one with large } \\
1 \text { and one colonic angiolipoma }\end{array}$ \\
\hline Yung IS et $a l^{[15]}$ & $\begin{array}{l}\text { A submucosal lesion composed of mature adipose } \\
\text { tissue and small vessels with fibrin thrombi within } \\
\text { the vascular channels }\end{array}$ \\
\hline Manner M et al ${ }^{[17]}$ & $\begin{array}{l}\text { An angiolipoma with } 20 \% \text { vascular component and } \\
\text { mucosal ulceration }\end{array}$ \\
\hline Kwak HS et al $l^{[18]}$ & $\begin{array}{l}\text { Mature, higly vascular adipose tissue consistent with } \\
\text { angiolipoma }\end{array}$ \\
\hline Kato Ket $a l^{[20]}$ & $\begin{array}{l}\text { A circumbscribed proliferation of mature adipose and } \\
\text { vascular tissue surrounded by a thin to focally thick } \\
\text { fibrous capsule in the submucosa, with fibrin thrombi } \\
\text { in small capillaries }\end{array}$ \\
\hline & Matur \\
\hline Vand & $\begin{array}{l}\text { Angiolipoma with multiple small vessels and adipose } \\
\text { tissue }\end{array}$ \\
\hline Okuyama T et al ${ }^{[23]}$ & $\begin{array}{l}\text { Encapsulated by a thin layer of connective tissue, } \\
\text { arising in the submucosa and composed of mature } \\
\text { adipose tissue and proliferating capillaries, many } \\
\text { fibrin thrombi in capillary lumen }\end{array}$ \\
\hline Chen YY et al ${ }^{[24]}$ & $\begin{array}{l}\text { Encapsulated by a thin layer of connective tissue } \\
\text { arising from the submucosa, histologically was } \\
\text { comprised of mature adipose tissue and proliferative } \\
\text { blood vessels }\end{array}$ \\
\hline $\mathrm{K}$ & $\begin{array}{l}\text { Proliferated submucosal blood vessels and mature } \\
\text { adipose tissue. There was no fibrin thrombus }\end{array}$ \\
\hline
\end{tabular}

lesions ${ }^{[9,12,14,23,24]}$, and the cases in the literature are generally diagnosed based on abdominal pain, obstruction, invagination, intussusception, and acute or chronic bleeding.

Diagnosis of GIS angiolipomas can be made radiologically via contrast barium enema, enteroclysis, abdominal ultrasound, endoscopic ultrasound, abdominal tomography, or MRI before the polypectomy or resection if the lesion is large $e^{[9,15,17,18,20,23,24]}$. Large lesion size and the symptom are the main factors in the radiologic diagnosis, but final diagnoses are done histologically. There is filling-defect in gastrointestinal lumen detected by barium enema ${ }^{[24]}$ and enteroclysis ${ }^{[18]}$, hyperechoic lesion in transabdominal ultrasonography ${ }^{[17,24]}$, submucosal lesion in gastrointestinal wall in endosonography ${ }^{[9]}$, hyperechoic lesion in $\mathrm{CT}^{[3,9,14,17,20,23]}$, and central high signal intensity with peripheral iso-signal intensity on T1-weighted inphase images in $\mathrm{MRI}^{[18]}$.

Surgical resection is preferred to endoscopic resection in the case of broad-based or pedunculated large polyps due to risk of perforation and bleeding ${ }^{[9,10,11,12,17,18,20,24]}$. For pedunculated polyps, injection of epinephrine, or use nylon loop or metal hemostatic clip are suggested before polypectomy to decrease the risk of postoperative bleeding ${ }^{[14,23]}$. These patients can be treated by standard polypectomy. The level of urgency is also an important factor when choosing the most optimal treatment. In the case of intussusception ${ }^{[16,21]}$, obstruction ${ }^{[9,24]}$ or acute bleeding ${ }^{[12,19,22]}$, emergent surgery is generally suggested. In some cases, minimally invasive laparoscopic techniques can be performed successfully. A cecal lesion was treated successfully with laparoscopy-assisted ileocecostomy and a five-year follow-up showed no recurrence in this patient ${ }^{[22]}$.

Our patient was diagnosed by histopathologic evaluation after snare polypectomy of a single, small polyp with thin peduncle in the rectum. There was no complication after polypectomy. The peduncle was histologically normal. There were proliferated blood vessels and mature adipose tissue in the submucosa and no fibrin thrombus was found. Mature adipose tissue and proliferated blood vessels are the diagnostic components as defined in the literature. Fibrin thrombus in the vascular component is a common finding ${ }^{[5,11,20,23]}$. The histopathological findings of the cases in the literature are given in Table 2 .

The polyp was not responsible for the dyspeptic symptoms and constipation in our patient. Although the polyp could have caused rectal bleeding, no bleeding occurred in our patient. The lesion was thus considered as asymptomatic. The sigmoid angiolipoma in literature ${ }^{[23]}$ was asymptomatic, but $65 \mathrm{~mm}$ in diameter. Our case is the first rectal, small, asymptomatic angiolipoma diagnosed incidentally in the gastrointestinal tract.

Although angiolipomas are benign lesions among adipose tissue neoplasms, additional staining techniques are required to distinguish from malignant lipomatous forms like angioliposarcoma ${ }^{[27,28]}$. The resection material of our patient was stained by HMB45 and anti-smooth muscle antibody, and found negative for muscle fibers. The differential diagnosis was made between angiomyolipoma and angioliposarcoma.

In conclusion, it is important to remember that submucosal, sessile, or polypoid lesions in the gastrointestinal tract with or without symptoms can be an angiolipoma, a lipomatous tumor, although it is quite rare.

\section{REFERENCES}

1 Murphey MD, Carroll JF, Flemming DJ, Pope TL, Gannon FH, Kransdorf MJ. From the archives of the AFIP: benign musculoskeletal lipomatous lesions. Radiographics 2004; 24: 1433-1466

2 Punia RS, Jain P, Amanjit H, Singh R. Subcutaneous angiolipomas: a clinicopathological study of 12 cases. Indian J Pathol Microbiol 2005; 48: 197-198

3 Ferrozzi F, Rubino S, Uccelli M. Ileal angiolipoma in a patient with multisystemic manifestations of tuberous sclerosis: diagnosis with computerized tomography. Radiol Med 1998; 96: $403-405$

4 Vigili MG, Micozzi M, Moreschini G, Colacci AC, Masci P, Silvagni C. Oropharyngeal angiolipoma: a case study. Acta Otorhinolaryngol Ital 1999; 19: 348-351 
5 Choong KK. Sonographic appearance of subcutaneous angiolipomas. J Ultrasound Med 2004; 23: 715-717

6 Flaggert JJ, Heldt LV, Keaton WM. Angiolipoma of the palate. Report of a case. Oral Surg Oral Med Oral Pathol 1986; 61: 333-336

7 Lin SC, Wang TY, Hahn LJ. Angiolipoma of the tongue: report of a case. Ann Dent 1989; 48: 37-38

8 Brahney CP, Aria AA, Koval MH, Najjar TA. Angiolipoma of the tongue: report of case and review of literature. J Oral Surg 1981; 39: 451-453

9 Jensen EH, Klapman JB, Kelley ST. Angiolipoma of the esophagus: a rare clinical dilemma. Dis Esophagus 2006; 19: 203-207

10 DeRidder PH, Levine AJ, Katta JJ, Catto JA. Angiolipoma of the stomach as a cause of chronic upper gastrointestinal bleeding. Surg Endosc 1989; 3: 106-108

11 McGregor DH, Kerley SW, McGregor MS. Case report: gastric angiolipoma with chronic hemorrhage and severe anemia. Am J Med Sci 1993; 305: 229-235

12 Hunt J, Tindal D. Solitary gastric Peutz-Jeghers polyp and angiolipoma presenting as acute haemorrhage. Aust N Z J Surg 1996; 66: 713-715

13 Ferrozzi F, Tognini G, Bova D, Pavone P. Lipomatous tumors of the stomach: CT findings and differential diagnosis. $J$ Comput Assist Tomogr 2000; 24: 854-858

14 Mohl W, Fischinger J, Moser C, Remberger K, Zeuzem S, Stallmach A. Duodenal angiolipoma -- endoscopic diagnosis and therapy. Z Gastroenterol 2004; 42: 1381-1383

15 Jung IS, Jang JY, Ryu CB, Hong SJ, Kim JO, Cho JY, Lee JS, Lee MS, Jin SY, Shim CS, Kim BS. Angiolipoma of the duodenum diagnosed after endoscopic resection. Endoscopy 2004; 36: 375

16 Kaneko T, Karasawa $Y$, Inada H, Tamura $Y$, Yamamura N, Iijima Y, Nagata A, Oohata T, Shirota H, Nakamura T, Hara E. An adult case of intussusception due to inverted Meckel's diverticulum accompanied by angiolipoma. Nihon Shokakibyo Gakkai Zasshi 1996; 93: 260-265

17 Manner M, Scholz E, Wehrmann M, Stickel W. Invagination caused by angiolipoma of the small intestine--a rare cause of occult gastrointestinal hemorrhage. Chirurg 2001; 72: 305-307

18 Kwak HS, Kim CS, Lee JM. Small intestinal angiolipoma: MR imaging appearance. Abdom Imaging 2003; 28: 515-517

19 Aouad K, Texier P, Bloch F, De Labriolle-Vaylet C, Bouillot JL. Benign angiolipoma of the Bauhin valve causing severe digestive tract bleeding. Gastroenterol Clin Biol 2000; 24: 686-688

20 Kato K, Matsuda M, Onodera K, Sakata H, Kobayashi T, Kasai S. Angiolipoma of the colon with right lower quadrant abdominal pain. Dig Surg 1999; 16: 441-444

21 Saroglia G, Coverlizza S, Roatta L, Leli R, Fontana D. Angiolipoma of the cecum. Minerva Chir 1996; 51: 59-62

22 Vandamme J. Angiolipoma of the colon. Acta Gastroenterol Belg 1964; 27: 750-757

23 Okuyama T, Yoshida M, Watanabe M, Kinoshita Y, Harada $Y$. Angiolipoma of the colon diagnosed after endoscopic resection. Gastrointest Endosc 2002; 55: 748-750

24 Chen YY, Soon MS. Preoperative diagnosis of colonic angiolipoma: a case report. World J Gastroenterol 2005; 11: 5087-5089

25 Strotzer M, Paetzel C, Feuerbach S. Multiple hepatic angiolipomas: a case report and review of literature. Eur Radiol 1999; 9: 259-261

26 Huber C, Treutner KH, Steinau G, Schumpelick V. Ruptured hepatic angiolipoma in tuberous sclerosis complex. Langenbecks Arch Chir 1996; 381: 7-9

27 Zhang SH, Cong WM, Xian ZH, Wu WQ, Dong H, Wu MC. Morphologic variants and immunohistochemical features of hepatic angiomyolipoma. Zhonghua Binglixue Zazhi 2004; 33: 437-440

28 Tsui WM, Ng IO, Colombari R, Pea M. Hepatic angiomyolipomas. Histopathology 1993; 22: 602-603

29 Bowen JT. Multiple subcutaneous hemangiomas, together with multiple lipomas, occurring in enormous numbers in an otherwise healthy, muscular subject. Am J Med Sci 1912; 144: 189-192
30 Howard WR, Helwig EB. Angiolipoma. Arch Dermatol 1960; 82: $924-931$

31 Saydam L, Bozkurt MK, Ugur MB, Ozcelik T, Kutluay L. Angiolipoma of the neck: a case report. Ear Nose Throat J 2005, 84: 375-377

32 Hamakawa $\mathbf{H}$, Hino $H$, Sumida $T$, Tanioka $H$. Infiltrating angiolipoma of the cheek: a case report and a review of the literature. J Oral Maxillofac Surg 2000; 58: 674-677

33 Ali MH, el-Zuebi F. Angiolipoma of the cheek: report of a case. J Oral Maxillofac Surg 1996; 54: 213-215

34 Shohet JA, Simpson B, Coleman JR, Geiger XJ. Angiolipoma presenting as a nasal mass. Otolaryngol Head Neck Surg 1998; 118: 848-849

35 Pfannenstiel TJ, Boseley M, Roach L. A case of paranasal sinus angiolipoma. Laryngoscope 2003; 113: 1080-1081

36 Hattori H. Epidural angiolipoma is histologically distinct from its cutaneous counterpart in the calibre and density of its vascular component; a case report with review of the literature. J Clin Pathol 2005; 58: 882-883

37 Petrella G, Tamburrini G, Lauriola L, Di Rocco C. Spinal epidural angiolipoma complicated by an intratumoral abscess. Case report. J Neurosurg 2005; 103: 166-169

38 Konya D, Ozgen S, Kurtkaya O, Pamir NM. Lumbar spinal angiolipoma: case report and review of the literature. Eur Spine J 2006; 15: 1025-1028

39 White NJ, Cochrane DD, Beauchamp R. Paraparesis caused by an angiolipomatous hamartoma in an adolescent with Proteus syndrome and scoliosis. J Neurosurg 2005; 103: 282-284

40 Shuangshoti S, Wangsuphachart S. Angiolipoma of suprasellar region. J Med Assoc Thai 1995; 78: 631-634

41 Ewalt DH, Diamond N, Rees C, Sparagana SP, Delgado M, Batchelor L, Roach ES. Long-term outcome of transcatheter embolization of renal angiomyolipomas due to tuberous sclerosis complex. J Urol 2005; 174: 1764-1766

42 de Perrot M, Licker M, Robert J, Nicod L, Spiliopoulos A. Successful combined lung and kidney transplantation for pulmonary lymphangioleiomyomatosis and renal angiolipomas. Eur Respir J 1998; 12: 1479-1481

43 Verna C, Mosso L, Moncelli G, Monaco A. Renal angiolipoma associated with bilateral double ureter. A clinical case. Minerva Urol Nefrol 1997; 49: 39-44

44 Alvo M, Passalacqua W, Castro P, Wash A. Tuberous sclerosis with probable bilateral renal angiolipoma. Rev Med Chil 1988; 116: $934-937$

45 Ramacciato G, Lombardi M, Amodio PM, Mercantini P, Petrocca S, Stipa F, Di Giacomo G, Bellagamba R, Puce E, Ziparo V. Laparoscopic adrenalectomy: a worthwhile procedure performed in a general surgery department. Am Surg 2003; 69: 427-433

46 Maurea S, Mainolfi C, Wang H, Varrella P, Panico MR, Klain M, Rossi R, Cremona F, Bazzicalupo L, Salvatore M. Positron emission tomography (PET) with fludeoxyglucose F 18 in the study of adrenal masses: comparison of benign and malignant lesions. Radiol Med 1996; 92: 782-787

47 Morakkabati-Spitz N, Schild HH, Leutner CC, von Falkenhausen M, Lutterbey G, Kuhl CK. Dynamic contrastenhanced breast MR imaging in men: preliminary results. Radiology 2006; 238: 438-445

48 Palazzo JP, Coté SA. Primary angiolipoma of the thyroid gland: a case report. Int J Surg Pathol 2005; 13: 305-307

49 Reilly JS, Kelly DR, Royal SA. Angiolipoma of the parotid: case report and review. Laryngoscope 1988; 98: 818-821

50 Gámez García P, de Pablo Gafas A, Salas Antón C, Santolaya Cohen R, Madrigal Royo L, Varela de Ugarte A. Mediastinal dumbbell angiolipoma. Arch Bronconeumol 2002; 38: 545-546

51 Feinfield RE, Hesse RJ, Scharfenberg JC. Orbital angiolipoma. Arch Ophthalmol 1988; 106: 1093-1095

52 Kiaer HW. Myocardial angiolipoma. Acta Pathol Microbiol Immunol Scand A 1984; 92: 291-292

53 Rajagopalan S. An unusual pediatric scrotal lump. Indian J Pediatr 2005; 72: 801

54 Sciot R, Akerman M, Dal Cin P, De Wever I, Fletcher CD, 
Mandahl N, Mertens F, Mitelman F, Rosai J, Rydholm A, Tallini G, Van den Berghe H, Vanni R, Willen H. Cytogenetic analysis of subcutaneous angiolipoma: further evidence supporting its difference from ordinary pure lipomas: a report of the CHAMP Study Group. Am J Surg Pathol 1997; 21: 441-444

55 Ji Y, Zhu X, Xu J, Zhou J, Tan Y, Wang J, Fan J, Zhou Y. Hepatic angiomyolipoma: a clinicopathologic study of 10 cases. Chin Med J (Engl) 2001; 114: 280-285

56 Hirasaki S, Koide N, Ogawa H, Ujike K, Shinji T, Tsuji
T. Tuberous sclerosis associated with multiple hepatic lipomatous tumors and hemorrhagic renal angiomyolipoma. Intern Med 1999; 38: 345-348

57 Cina SJ, Radentz SS, Smialek JE. A case of familial angiolipomatosis with Lisch nodules. Arch Pathol Lab Med 1999; 123: 946-948

58 Chung JY, Ramos-Caro FA, Beers B, Ford MJ, Flowers F. Multiple lipomas, angiolipomas, and parathyroid adenomas in a patient with Birt-Hogg-Dube syndrome. Int J Dermatol 1996; 35: $365-367$

S- Editor Liu Y L- Editor Ma JY E- Editor Zhou T 